\title{
Bureaucratic Capacity of the Public Administration: Judiciary Function of Ecuador in the Pandemic
}

\author{
Nancy del Rocio Flores Hinojosa, Liliana del Carmen Morillo Acosta \\ Administrative Sciences Department, Central University of Ecuador, Quito, Ecuador \\ Email:nrflores@uce.edu.ec, lmorillo@uce.edu.ec
}

How to cite this paper: del Rocio Flores Hinojosa, N., \& del Carmen Morillo Acosta, L. (2021). Bureaucratic Capacity of the Public Administration: Judiciary Function of Ecuador in the Pandemic. Open Journal of Social Sciences, 9, 334-347.

https://doi.org/10.4236/jss.2021.98023

Received: June 18, 2021

Accepted: August 13, 2021

Published: August 16, 2021

Copyright $\odot 2021$ by author(s) and Scientific Research Publishing Inc. This work is licensed under the Creative Commons Attribution International License (CC BY 4.0).

http://creativecommons.org/licenses/by/4.0/

(c) (i) Open Access

\begin{abstract}
Bureaucratic capacities variable (effect) changed by government measures (cause) as a result of the health emergency. It displaced the bureaucratic capacities towards a new reality with its effect on institutional performance. It aimed to analyze the current state and the effect of the measures adopted during the pandemic on the bureaucratic capacities of the judicial function. The research is qualitative and transversal. Information was obtained by two sources. The first was a semi-structured interview applied using convenience sampling; the second was a documentary inquiry. Information was processed according to the bureaucratic capacities in public administration. It was analyzed a causal relationship supported in the logical-deductive perspective to build knowledge. The challenges faced by the Judicial Council were analyzed in four dimensions: deconcentrating, institutional expansion, social participation and performance evaluation. A theoretical argument was developed as a basis for analysis. It was analyzed under the cause-effect logic the impact of government measures on bureaucratic capacities. The bureaucratic capacities due to governmental measures in the judicial function are close to the limit of its functionality as an institution, which compromises its services in the present and it possible collapse in a future.
\end{abstract}

\section{Keywords}

Institutional Capacity, Administrative Capacity, Political Capacity, State Capacity, Council of the Judiciary

\section{Introduction}

Searching for information for the present documents has been a problem for the following reasons. The lack of writings related to the Ecuadorian bureaucratic 
capacity, as well as the issue of state capacities in the field of social policies, a concept that has been given relevance since the 90s, especially in the redesign of public action. The issue of state capacities is pointed out in a broader and more recent concern for the construction and/or reconstruction of the bodies empowered to govern complex processes such as those that a country has experienced and especially in the judicial function, during the last years.

Some years ago, in 2001, in the interview that Professor Manuel Atienza made with Robert Alexy, he asked him how he saw the future of Law, to which the German professor replied that "the role of the judiciary will probably tend to increase in the future." Then expressing the reasons he had for being convinced of this omen: On the one hand, there is the complexity of social and economic relations (Vila Casado, 2021). On the other hand, the role of tradition and conventions is crumbling for law teachers who imagined that, at some point in that uncertain future, the pandemic caused by the coronavirus (COVID-19) would occur with the devastating consequences that we know. But even in it and perhaps because of it, the role of Law, and the judicial power (Ricardo, 2011), in its application and interpretation, are called to be transformed, at least in some sense (Marrero, 2020).

This document analyzes the bureaucratic capacity of one of the functions of the state, the judicial function of Ecuador in the framework of the health emergency declared not only at the country level but also at the global level, which led to the national government ruling a state of emergency in the entire country as of March 16, 2020, (executive decree), and as a consequence, triggered a curfew, thus paralyzing both the public and private sectors that offer goods and services. Excluding, of course, sectors that, by their very nature, cannot paralyze their activities, such as health, security, justice, the latter being where we will focus the study.

This work is organized as follows: first, the main transformations that have occurred in social policy are explored, as well as the main challenges faced by the council of the judiciary, as an administrative body of the judicial function. In a second moment, the theory is evaluated in order to establish general parameters for the analysis of state capacity. The third moment determines the current status and the effect of the measures adopted by the government as a result of the pandemic on the state capacities of the judicial function. The objective of the work is to carry out an analysis of the current state and the effect of the measures adopted by the pandemic on the bureaucratic capacities of the judicial function.

\section{Materials and Methods}

The research is qualitative, transversal. The unit of analysis is the bureaucratic capacities in the judicial function of Ecuador. The source of empirical information is the considerations of the members of the institution. In addition, a documentary inquiry process associated with the issue was carried out within the institution itself (internal) and from the state to the institution (external). The 
fact that the judicial function is a public entity and is subject to the transparency law allows access to information as it is considered public. For the collection of empirical information, the interview technique was used, specifically the semistructured interview instrument. Agenda was developed for each type of bureaucratic capacity. The selected sample is non-random (trial sampling).

The criteria for selecting people were based on their work as a public servant, access to information and knowledge. The judgment of one of the authors was used based on her experience as a Human Resources manager within the institution. The interview number was thirty-one. The certainty of the meaning of what was measured (validity) was supported by the review of the interview formats by five PhD students in Public Administration. The reliability expressed in the consistency or stability of the interviews materialized in the repetition of ten interviews in a period of two months, the result was stability in the criteria. In addition, the fact of using the Triangulation of researchers or analysts and the agreement in the criteria of the interviewees are two aspects that favor compliance with the criteria of validity, reliability and reliability.

For the analysis of the data collected in the interviews, each researcher individually processed the interviews and the results were compared, finding similarity in the criteria of the interviewees. Based on these criteria, a causal relationship is studied under deductive logic, starting from the premises developed in the theory received in the subject set out in the theoretical aspects on state capacity, and analyzing the events that occurred in the legal function at which it is required. light of the discussed theory and an explanation of the state of bureaucratic capacities is projected.

The research complied with the ethical principles of informed consent, the interviewees were informed of the objective of the research and scope. Participation was voluntary. The knowledge derived from this research is intended for the growth of science and the common good of society. In addition, it was approved by the ethics committee of the Faculty of Administrative Sciences.

\section{Results}

This section develops a vision of the problems and challenges from the analysis of four dimensions: deconcentrating, institutional expansion, social participation and performance evaluation.

The Council of the Judiciary was created with the 2008 constitution, as a governing body, administration, oversight and discipline of the judicial function (Guapulema Cali, 2014) time in which profound transformations have been generated in the whole of its public institutions, taking into account Consideration that within its scope of intervention or the role of administrator that it has in front of the jurisdictional, autonomous and auxiliary bodies. Beyond the differences regarding the mode of administration that each of these organizations faced towards the new course of the administration of justice.

In these last 20 years, the different bodies have made great advances in ad- 
ministrative matters such as: physical, organizational, human resources, and technological structures; since, previously the indicated bodies were administered with personnel from the different judicial dependencies. As the authors of the contribution (Isuani, Pereyra, \& Serafinoff, 2018) well point out, technological activities and their regulation have tended to generate standardizations that transcend national borders, and contribute to the modeling of the profiles of officials and technicians who work in the various organisms that make up the institutional system.

The administrative and financial deconcentration process implied the creation of autonomous bodies such as: The State Attorney General's Office and the Public Defender's Office. Fact that increased the number of prosecutors and public defenders. The deconcentration of the Provincial Directorates of the Council of the Judiciary in each of the 24 provinces of the country, allowed to broaden the Judicial Function, as well as the centralism characterized within the institution, in order to make management more efficient and help solve the problems caused locally. For the state, the wage bill earmarked for this state function represented an increase. If we add to this, the growth in the number of notaries who are part of the auxiliary body of the judicial function that, although they are generators of resources for the state, but not in a sufficient quantity to cover the needs of the judicial function.

The deconcentrating generated in the administrative body, has allowed them to be agencies that exercise powers by delegation of the highest authority, having as their main task to positively resolve their administrative, financial and political deconcentrating, in order to ensure the minimum levels of quality of services. It could be noted that the independence of the autonomous bodies, although they have administrative and financial autonomy, depend directly on the decisions that the Council of the Judiciary makes regarding administrative capacity, which has led the Prosecutor's Office General of the State, is proposing to the National Assembly the modification of the Organic Code of the Judicial Function and it is allowed to have its own administrative capacity for the management of this establishment of the Ecuadorian state, which would constitute a possible decentralization of this institution and therefore to maintain its absolute power, as the author (Isuani et al., 2018) points out, that the possibility of managing certain degrees of autonomy in an organization is a function of the ability of the actors to preserve or expand their quotas of can.

This widening in one of the functions of the state, although they generated great advances and institutional changes within the public administration, taking advantage of the economic resources that the country had at the time, due to the different income from the sale of oil, foreign exchange of migrants, primary sources considered in the elaboration of the general state budget.

Although the expansion carried out in the judicial function since 2011 is a fact that is confirmed with the implementation of new administrative and judicial units in different matters throughout the country, based on a new management model, in order to seek a more intense and closer interaction between citizens 
and the institution, for which a greater amount of resources was demanded: human, financial, technological, which require an increase in their volume and capacity due to the problems that today day they must be addressed, they have caused that the events that have arisen worldwide, and especially in our country, have a weakening in its economy, affecting the budgetary resources allocated to social spending.

In the technological field and the organizational form, Stinchcombe, cited in (Hall Richad, 1996), argues that, the technological conditions available at the time of the formation of an organization establish in a certain way new organizational forms, leading it to persist over time, regardless of gradual changes in technology; developing in this way new organizations and new organizational forms.

Social participation has also been part of the judicial transformation, if it is considered that it is part of one of the functions of the state, whose main reason is to establish accountability mechanisms for public sector institutions and entities, and help citizen oversight and social control processes; through the participation of citizens in decision-making regarding the management of resources and actions that have an impact on the development of their communities, being their legitimate right of citizenship more than a concession with the institutions.

In recent years, the participation of civil society has not considered from its perspective the strengthening of a citizenry, active, full and capable of controlling public management, taking into account that the Council for Citizen Participation and Social Control, expressed expressions of patronage and favoritism when appointing the highest authorities of the most notable institutions of the state, among them the Council of the Judiciary; more than that, they never exercised true control and monitoring of the management carried out by the different authorities on duty.

A very important aspect, both in the judicial function and in the public sector in general, has been the evaluation of the periodic performance to which public servants have been subjected, thus promoting public action in matters of social policy; as well as the promotion of professionalization and training of public servants in order to provide a better service to citizens.

Both in the judicial function, as in the other public institutions in the last three years, the performance evaluation of their public servants has stopped, adducing, due to the constant change in the institutional strategic level; It can be said that this is another problem and challenge associated with progress in monitoring and evaluation mechanisms; letting it be noted that there is no culture that encourages the active use of these evaluative processes, which allow obtaining results to measure the performance of public servants and through it the management of their highest authorities.

The description of these four aspects shows a set of problems that turn into challenges for the institution. It is visible that an important part of them is associated with the lack and deficits of administrative and political capacities, in short, their state capacity. 


\section{Theoretical Aspects of State Capacity}

We lack systematic studies that describe and explain the concrete modes and configurations that the state bureaucracy has acquired. Likewise, little progress has been made in analyzing the changes in the types and levels of incidence that the bureaucracy has in the production of public policies and in the modes of interaction within it, and between it and the social actors.

A fundamental first step consists of defining what is understood by state capacities. (Souza \& Fontanelli, 2019), for example, defines it as the set of tools and institutions available for a government to establish goals, configure them in policies and implement them. For their part, Hilderbrand and Grindle, cited in (Repetto, 2003), emphasize state capacity as the ability to perform appropriate tasks with effectiveness, efficiency and sustainability. Likewise, Migdal, also cited in (Repetto, 2003), defines it as the ability of state leaders to use state organs in order to get the members of a society to do what they want to be done. State capacities are considered as contents that the State develops in the implementation of public policies, thus these capacities provide resources: administrative, technical, political and institutional for solving problems in society.

While, bureaucratic quality can be conceptualized when different combinations of the following conditions are present: meritocratic, predictable, longterm rewarding recruitment, rules for hiring, public service career and layoffs that replace arbitrary layoffs; filling positions through internal promotion; trained professionals capable of acting as an expert or as a generalist; professionals free from external influences; control through administrative and legal norms (accountability) (Souza \& Fontanelli, 2019). Although, this document proposes a concept of bureaucratic capacity based on the management carried out by the highest administrative body of the Ecuadorian judicial function, for which its structure is composed of four bodies that, although they are part of the judicial function, maintain their own administrative, economic and financial autonomy with the exception of the National Court of Justice (not financial).

The institutional capacity of the judicial function is closely related to the other functions of the state, to face the public problems that arise, characterized by an economic, political and social system, as well as with certain social actors. Added to this is the international context. Although the institutional capacity does not depend only on the administrative organizations, but also on the constitution and on certain socio-political actors involved in a certain field of public action. As mentioned (Guapulema Cali, 2014), organizations are closed systems that can dispense with or completely isolate themselves from the larger web of social relations to which they belong and from the general institutional framework that derives from said web, these are, from their context; framed of course, in certain rules, formal and informal that govern politics, composed of a series of institutions defined for the administration of public policy.

While administrative capacity makes mention of the technical bureaucratic skills of the state apparatus required to implement its institutional objectives, the 
author (Rosas Huerta, 2008) highlights two important factors, focused on human resources and organization. While the author Isuani et al. (2018), emphasizes that each unit, arising from that principle, will fulfill a certain role within the group will have a certain autonomy of decision and action (assigned autonomy) so that it can fulfill the same, reason For which, since the Judicial Function is one of the five functions of the State with autonomy, administrative, economic and financial for its administration, although, through its notarial and jurisdictional auxiliary bodies, it makes a considerable contribution to the state coffers , but this is not enough to cover all the expenses that this function of the State must carry out in proportion to the quantity and quality of the service that it must offer to the citizens; For this reason, the state must assume the difference that is required by this function, which in a certain way affects its autonomy, by the establishment of certain conditions that result from such assignments, affecting in a certain way its actions and decisions.

The great social transformations in history and changes are achieved through organization, for which it becomes necessary to make an organizational analysis from different perspectives depending not only on the levels at which it occurs, but also on the type of organization, for what which, the administrative capacity has the task of evaluating the state of the organization, since they have the ability to do good or bad, taking into consideration that some may be somewhere in the middle, that is, organizations have results, although these do not are entirely organizational (Hall Richad, 1996).

Rosas Huerta (2008), political capacity refers to the political interaction that, framed in certain rules, norms and customs, established by the actors of the State and the political regime with the socioeconomic sectors and with those who operate in the international context, that is, the participating actors and the ways in which they participate, forms of negotiation and in the power struggle (Bravo Hidalgo \& León González, 2018). Crozier cited in (Isuani, 1998), emphasizes that power is not the simple reflection and product of an authority, organizational or social structure, since, basically, it is nothing other than the always contingent result, of mobilization, by the actors, from the pertinent sources of uncertainty that they control in a given game structure, by their relationships and transactions with the other participants in that game.

Morgan (1990), states that, although technology has allowed users the ability to achieve surprising results in the performance of an activity, it has also become a tool capable of manipulating, controlling and making it work efficiently for their own ends, becoming dependent in some indispensable way that can even convert the organization's income into expenses. Technology is considered to have a decisive impact on power relations, often leading to conflicts between authority and operational levels and between different groups within the organization.

Grindle cited in (Alonso, 2007), considers state capacity from 4 dimensions linked to the functions that the state must exercise: institutional capacity, establishment and effective application of rules that govern political and economic 
interactions. Technical capacity, ability to analyze and manage macroeconomics and public policy options. Administrative capacity, ability of state organizations to implement the supply of goods and services. Finally, political capacity, ability to take into account and respond to the demands from society.

While for the author Alonso (2007), she identifies two types of capacities: technical-administrative capacity and relational capacity; in the first, he focuses on the internal capacities of organizations. while the second prioritizes the relationship of the state apparatus with the socioeconomic environment. Although technical capacity is included within the context of administrative capacity, but highlighting the emergence of the societal relationship as an independent capacity that includes political capacity within it, since there is a non-exclusive link between relations with society for the elaboration of public policies.

\section{Discussion}

\section{Effects of Government Measures on Bureaucratic Capacities}

For the development of the section, the theory of Merilee Grindle is used, which identifies four levels of analysis that affect state capacities, however, this work will focus on administrative capacity as it is directly related to the case study:

Institutional capacity: the professionalization of the public function and its link with state capacities, training and personnel development, continues to be a challenge for national, sub-national and local public administrations, based on the fact that the efforts made by some regional states have been developed, have been reflected mainly in the enactment of regulatory frameworks and other related regulations, rather than in the implementation of technical policies aimed at improving the quality of public management (Picado Madrigal \& Umaña Bonilla, 2014).

The Constitution of the Republic of Ecuador (Guapulema Cali, 2014) in its article 234, states that:

"The State will guarantee the formation and continuous qualification of the servants and public servants through the schools, institutes, academies and programs of formation or training of the public sector; and coordination with national and international institutions that operate under agreements with the State.".

It is in the capacity that the national government, as well as the authorities of the different institutions of the public sector, make effective the application of this provision enshrined in the maximum norm of the state. Ecuador is one of the countries that has considered the training of public servants as a public policy, during the last 10 years the administration of human resources has been transformed in order to improve the management of the public function, taking advantage of the instead, of certain technological, communicational, and social innovations that nowadays allow making substantial changes in public organizations and in this way moving towards what is known as New Public Management. 
Technical capacity: the lack of coordination between departments and programs, one of the main problems faced by contemporary governments, is largely attributed to the lack of coordination that exists between the design and implementation of policies. In this context, coordination as a concept refers to "the need to ensure that the different organizations, public and private, responsible for the formation of public policies, work together so as not to produce redundancy or gaps in the delivery of services." by Peters, cited in (Licha \& Molina, 2006). For them, institutional action will be exercised with the leadership and vision necessary to direct policies from a set of common values and ideas. Resorting to effective means of communication that allow all public servants to work together and provide efficient public services and, if necessary, go further, as noted by Peters, quoted in (Licha \& Molina, 2006) "to reach the point of generating cooperation to do organizational missions are compatible and thus overcome contradictions", for which the institution has had to adopt strategies that make it possible not to paralyze the service, considering its relevance in the State.

Political capacity, in charge of responding to demands from society, for which the ability to "manage transversality" as Echeberría calls it cited in (Licha \& Molina, 2006) means promoting the so-called "culture of coordination" in the organization, that is, the creation of a shared sense of the mission and vision of the organization.

Today's organizations are considered as systems of government, with models of autocracy, democracy, bureaucracy and technocracy; that in any of these, parallels are drawn between organizations and political systems, characterizing in this way in terms of a particular style of political rules (Morgan, 1990); Since the judicial function is part of the five functions that make up the state, it is no less true that its representatives are elected in a certain way under the power and administration of the executive, who exerts influence on the administration that they perform in their functions, applying according to the circumstances a mixture of any of these models.

One proposal would lie in having an organization that maintains organizational policies, focusing on relationships between interests, conflicts and power, since this allows people to think and act in different ways and give a positive meaning to the various power games they try to impose. In the organization.

Organizations generally consider four objectives as indicated in (Mintzberg \& Comajuncosa, 1992), which are: ideological, formal, inherent to shared systems and personal; Although all of them are important, the ideological ones directly related to the mission of the organization, specifically with the preservation, extension and improvement, have been displaced, concentrating on the objectives of systems, because they are themselves a system as such; if we consider what the author pointed out that the objectives of systems are the very power of the organization because they are a dynamic equilibrium. Whereas, personal objectives can be whatever the agents want them to be; the same occurs with formal objectives, with the only difference that when they are imposed through bureaucratic control, they become operational. 
Marx cited in (Oszlak, 1978), argues that the existence of the state bureaucracy responds to particular interests of civil society, and that, in the process of satisfying demands associated with such interests, the bureaucracy developed its own, which are not necessarily compatible with the general interest. While, (Souza \& Fontanelli, 2019), in his writing, "emphasizes that the concept of high-quality bureaucracy is understood as a combination of an ontological approach to concepts with a structure of familiar similarity".

Administrative capacity: state organizations must seek the necessary resources to provide goods and services, for which it is necessary to create capacities to articulate actors and promote the formation of social capital and generate a public institution that is conducive to institutional development. of certain conditions, individual (institutional actors), and, on the other hand, organizational, (in policies and in human resource management practices) (Picado Madrigal \& Umaña Bonilla, 2014), such as: recruitment, selection, promotion, promotion, salaries and public service career; to the formation, training of human resources and the development of the state organizational apparatus; professionalization based on merit-based recruitment; system of rewards and punishments; individual capacity of the actors responsible for tasks in terms of information, motivation, knowledge-understanding and required skills, among other aspects.

The authors in their journal Public Administration and Society highlight the importance that human resources have acquired in recent years in public organizations, giving the true value that people have for the achievement of organizational objectives, and therefore the need arises to find policies, strategies and mechanisms to improve human resource management; while, in local management, they highlight that human resources acquire a singular importance because they become a strategic element for local development.

Based on the right to work established in the Constitution of the Republic of Ecuador (Guapulema Cali, 2014), in article 326, numeral 15, it is based on the following principle:

"The paralysis of the public services of health and environmental sanitation, education, justice, firefighters, social security, electricity, drinking water and sewerage, hydrocarbon production, processing, transportation and distribution of fuels, public transportation, mail and telecommunications is prohibited. The law will establish limits that ensure the operation of said services."

Taking into account the serious health crisis that not only the country is going through, but the entire world, which has economically convulsed all sectors, and even more so the public sector, which, due to the reduction in the economic resources allocated to the issue of resources human resources, the national government has requested the governing body of human resources, such as the Ministry of Labor, the optimization of resources in the different state institutions; so much so that the government itself, in an effort to reduce the size of the state, through various executive decrees, has suppressed and merged state organizations, providing in certain cases, in relation to human talent, evaluation processes are carried out, selection and rationalization of human talent. 
Among the adjustment policies adopted by the central government, the human resources administration system in the field of public organizations, are: suppression of items, elimination of occasional service contracts, elimination of contracts under the labor code figure, reduction and flexibility of organizational structures, restructuring of salary scales, these guidelines characterize these reforms, leading to the reduction of personnel plants and public sector salaries.

In the Ministerial Agreement: Procedure for the abolition of public sector posts, cited in (Montalvo Paz, 2020), issued by the Minister of Labor, two special considerations have been taken into account:

“1) Functional and/or technical reasons: Are those that occur when there are modifications in the attributions and/or competencies of the institution or that are derived from the study by internal restructuring processes, optimization, rationalization, merger, merger by absorption, division, deletion, elimination, subsumption and others of a similar nature in accordance with article 45 of the Organic Administrative Code.

2) Economic reasons: They are those that are generated by adverse budgetary conditions of the institutions or the State, which force the adoption of measures to optimize economic resources that allow the prevalence of the provision of public services."

On the subject of the elimination of items, those positions that have the figure of permanent or permanent appointment would be considered, positions that due to the time of service they have become part of the public service career, which although, currently they do not constitute the vast majority within the public sector; Therefore, by eliminating these items, the professionalization of the administrative career, aimed at strengthening the public administration, would be diminishing.

To create a successful integrated work, it is necessary to strengthen a set of capacities related to the knowledge and tools necessary to integrate work teams in considerations not vulnerable to the health emergency, through planning, the determination of roles and responsibilities of each server is very important to achieve institutional objectives (Licha \& Molina, 2006).

In the scientific contribution (Oszlak, 1978), he points out that the absence of systematic studies on the methodological apparatus, the global theories in matters of organization and administration; and, the lack of social, cultural and historical contextualization of various approaches have implied that the state bureaucracy is analytically distinguishable from other organizations, since despite their similar attributes, their nature and the role they play varies according to the social context. And the historical moment considered; becoming necessary the identification of distinctive features that allow looking at the difference of state bureaucracies with other social subjects (Hernández \& Hidalgo, 2020).

The different administrative reforms, not only that allow us to see how the conceptions of the causes of a supposed bureaucratic unproductiveness were changing, but also the inherent limitations of their conception of administrative change; Their first strategy, the "depersonalization" of the administrative organ- 
ization led to subordinate individual behavior to the functionality of the structural arrangements, for which they introduced changes to the regulatory framework applicable to the organization in order to obtain improvements in the efficiency or effectiveness of bureaucratic activity. The second strategy was to raise the need for "awareness", the improvement of values, through individual training, to make public servants leaders, with true dedication and motivation, valuing the individual objectives that frame within the regulatory framework institutional; When considering that these two strategies were not enough, another one was sought, such as "participationism", that is, making the servants participate in the processes of formulating objectives with an involvement of units and even society in general (Oszlak, 1978).

\section{Conclusion}

The bureaucratic capacities of the council of the judiciary during the health emergency have been affected by institutional, technical, administrative and political changes. In order to maintain the functionality of the judicial function, safeguard the safety and health of the personnel, it has been coordinated with various actors, at the local and national level, resulting in the implementation of the teleworking modality, the use of the electronic signature, mechanisms technological "web procedure", the use of telematic means for the different hearings or appearances in the different judicial units; For the provision of the notarial service, an inter-institutional technological system has been adapted, which will allow the physical presence of the participants to be replaced by remote intervention systems, digital certification of acts, contracts that do not necessarily require physical verification of the act or fact; With the different functions of the state, it has elaborated the Organic Law of Humanitarian Support to combat the health crisis derived from Covid-19, which was published through the official registry 229 of June 22, 2020, in order to establish tools necessary to face the health and economic consequences of the pandemic.

As negative effects of the measures adopted by the national government that affect the entire public sector and directly to the judicial function, the following are mentioned: with the implementation of the teleworking modality, the working day was reduced in a special way for those public servants that due to the nature of their functions cannot be executed under the indicated modality; lack of training in the use of the different computer tools created by the emerging need; The suppression and merger of public institutions are part of the process of restructuring the state, declared by the executive, leaving many people who are in the public sector unemployed, including those who belong to the judicial function, as a consequence of the fact that this year's fiscal programming is affected by the decline in the price of crude oil and the slowdown in economic growth, so that the authorities of the judiciary council have a long way to go in the search for financial resources to maintain an institution at the height of the demands of the citizenship in order not to leave the judicial service deprived. 
The Legal Function is close to the limit of its functionality as an institution, which compromises its services in the present and its reason for being in the future.

The research was carried out within the framework of the current Public Administration doctorate at the Universidad del Litoral financed by the Central University of Ecuador. There are no conflicts of interest between the authors and the research. The topic is within the coverage areas of the social sciences journal and provides a reflection of the evolution and the facto-perceptible state of bureaucratic capacities in the legal function of Ecuador impacted by government measures as a result of the pandemic developed in light of the theory of public administration. Each researcher participated fully in the development of the research and in accordance with teamwork without differences in contributions. In terms of $50 \%$ is expressed for each author. Thanks are expressed to the people who participated in the interviews with the five PhD students in Public Administration who acted as experts, to the ethics committee of the Faculty of Administrative Sciences.

\section{Conflicts of Interest}

The authors declare no conflicts of interest regarding the publication of this paper.

\section{References}

Alonso, G. V. (2007). Capacidades estatales, instituciones y política social. Prometeo Libros Editorial.

Bravo Hidalgo, D., \& León González, J. L. (2018). Divulgación de la investigación científica en el Siglo XXI. Revista Universidad y Sociedad, 10, 88-97.

Guapulema Cali, J. A. (2014). Derecho del buen vivir: El problema generado por el ser humano y el bien jurídico según los arts. 395, 12, 13, y 14, de la constitución de la república del Ecuador 2008. Universidad Central del Este.

Hall Richad, H. (1996). Organizaciones: Estructuras, procesos y resultados. Prentice Hall Hispanoamericana.

Hernández, A. B., \& Hidalgo, D. B. (2020). Fuzzy Logic in Business, Management and Accounting. Open Journal of Business and Management, 8, 2524-2544. https://doi.org/10.4236/ojbm.2020.86157

Isuani, F. J. (1998). Regulación y autonomía en las organizaciones. Universidad de Buenos Aires. Facultad de Ciencias Económicas.

Isuani, F., Pereyra, E., \& Serafinoff, V. (2018). Burocracias estatales en la mira. GIGAPP Estudios Working Papers, 5, 526-547.

Licha, I., \& Molina, C. G. (2006). Coordinación de la Política Social: Criterios para avanzar. Departamento de Integración y Programas Regionales, Instituto Interamericano.

Marrero, J. C. S. (2020). El juez tras el naufragio: La defensa jurídica de la familia en tiempo de pandemia. Revista Saber y Justicia, 2, 21-44.

Mintzberg, H., \& Comajuncosa, J. M. (1992). El poder en la organización. Universidad Nacional del Litoral.

Montalvo Paz, H. D. (2020). Propuesta de descripción, valoración y clasificación de puestos 
con enfoque en competencias para la empresa AKROS cia. Ltda. Universidad Nacional del Litoral.

Morgan, G. (1990). Imágenes de la organización (pp. 9-29). RA-MA Editorial. La organización como máquina.

Oszlak, O. (1978). Notas críticas para una teoría de la burocracia estatal. Revista Mexicana de Sociología, 40, 881-926. https://doi.org/10.2307/3539670

Picado Madrigal, C. M., \& Umaña Bonilla, N. (2014). Desarrollo de capacidad institucional en los centros de cuido municipales, de la Red Nacional de Cuido y Desarrollo Infantil: Análisis de los casos del Centro de Cuido de la Municipalidad de Cartago y la Municipalidad de Belén. Universidad Nacional del Litoral.

Repetto, F. (2003). Capacidad estatal: Requisito necesario para una mejor política social en América Latina. Paper presented at the VIII Congreso Internacional del CLAD sobre la Reforma del Estado y de la Administración Pública, Panamá, 28-31 October 2003, 1.

Ricardo, T. D. (2011). Validez del derecho: Análisis conceptual a partir de los modelos teóricos de Kelsen y Alexy. Revista Jurídica Mario Alario D’Filippo, 3, 105-111.

Rosas Huerta, A. (2008). Una ruta metodológica para evaluar la capacidad institucional. Política y cultura, No. 30, 119-134.

Souza, C., \& Fontanelli, F. S. (2019). $9^{\circ}$ Congreso Latinoamericano de Ciencia Política, organizado por la Asociación Latinoamericana de Ciencia Política (ALACIP). Universidad Nacional del Litoral.

Vila Casado, I. (2021). Fundamentos del derecho constitucional contemporáneo: Universidad Libre Sede Principal. Universidad Nacional del Litoral. 